-4 BIOTROPICA

\title{
The role of natural regeneration to ecosystem services provision and habitat availability: a case study in the Brazilian Atlantic Forest
}

\begin{tabular}{|c|c|}
\hline Journal: & Biotropica \\
\hline Manuscript ID & BITR-15-376.R2 \\
\hline Manuscript Type: & Paper \\
\hline Date Submitted by the Author: & 14-Sep-2016 \\
\hline Complete List of Authors: & $\begin{array}{l}\text { Strassburg, Bernardo; Pontifical Catholic University of Rio de Janeiro, , Rio } \\
\text { Conservation and Sustainability Science Centre (CSRio), Department of } \\
\text { Geography and the Environment,; International Institute for Sustainability } \\
\text { Barros, Felipe; International Institute for Sustainability } \\
\text { Crouzeilles, Renato; International Institute for Sustainability } \\
\text { Iribarrem, Alvaro; International Institute for Sustainability ; International } \\
\text { Institute for Applied Systems Analysis, Ecosystems Services \& Management } \\
\text { Santos, Juliana; International Institute for Sustainability } \\
\text { Silva, Daniel; International Institute for Sustainability } \\
\text { Boelsums, Jeronimo } \\
\text { Alves-Pinto, Helena; International Institute for Sustainability } \\
\text { Feltran-Barbieri, Rafael; International Institute for Sustainability } \\
\text { Latawiec, Agnieszka; International Institute for Sustainability }\end{array}$ \\
\hline Keywords: & $\begin{array}{l}\text { ecosystem services evaluation, natural regeneration, atlantic rainforest, } \\
\text { ecological restoration, connectivity }\end{array}$ \\
\hline
\end{tabular}

\section{SCHOLARONE \\ Manuscripts}




\author{
LRH: Strassburg et al. \\ RRH: Natural Regeneration Impact on Ecosystem Services
}

\title{
The role of natural regeneration to ecosystem services provision and
}

\section{habitat availability: a case study in the Brazilian Atlantic Forest}

\begin{abstract}
Bernardo B. Strassburg ${ }^{1,2,7}$, Felipe S. Barros ${ }^{2}$, Renato Crouzeilles ${ }^{1,2}$, Alvaro Iribarrem ${ }^{1,2,3}$, Juliana Silveira dos Santos ${ }^{2}$, Daniel Silva ${ }^{2}$, Jerônimo B. Sansevero ${ }^{4}$, Helena Alves-Pinto ${ }^{2}$, Rafael
\end{abstract} Feltran-Barbieri $^{2}$, and Agnieszka E. Latawiec ${ }^{1,2,4,5}$

${ }^{1}$ Rio Conservation and Sustainability Science Centre (CSRio), Department of Geography and the Environment, Pontificia Universidade Catolica do Rio de Janeiro, 22453-900, Rio de Janeiro, Brazil

${ }^{2}$ International Institute for Sustainability, Estrada Dona Castorina 124, 22460-320, Rio de Janeiro, Brazil

${ }^{3}$ International Institute for Applied Systems Analysis (IIASA), Ecosystem Services and Management Program, Schlossplatz 1, A-2361, Laxenburg, Austria

${ }^{4}$ Universidade Federal Rural do Rio de Janeiro (UFRRJ), Instituto de Florestas (IF), Departamento de Ciências Ambientais (DCA). BR 465, Km 07, 23890-000, Seropédica, Rio de Janeiro, Brazil

${ }^{5}$ Opole University of Technology, Department of Production Engineering and Logistics, Luboszycka 5, 45-036 Opole, Poland

${ }^{6}$ University of East Anglia, School of Environmental Science, Norwich, NR4 7TJ, UK

Received 29 December 2015; revision accepted 14 September 2016.

${ }^{7}$ Corresponding author; e-mail: b.strassburg@iis-rio.org 


\begin{abstract}
Natural regeneration provides multiple benefits to nature and human societies, and can play a major role in global and national restoration targets. However, these benefits are context specific and impacted by both biophysical and socioeconomic heterogeneity across landscapes. Here we investigate the benefits of natural regeneration for climate change mitigation, sediment retention and biodiversity conservation in a spatially explicit way at very high resolution for a region within the global biodiversity hotspot of the Atlantic Forest. We classified current land-use cover in the region and simulated a natural regeneration scenario in abandoned pasturelands, areas where potential conflicts with agricultural production would be minimized and where some early stage regeneration is already occurring. We then modelled changes in biophysical functions for climate change mitigation and sediment retention, and performed an economic valuation of both ecosystem services. We also modelled how land-use changes affect habitat availability for species. We found that natural regeneration can provide significant ecological and social benefits. Economic values of climate change mitigation and sediment retention alone could completely compensate for the opportunity costs of agricultural production over 20 years. Habitat availability is improved for three species with different dispersal abilities, although by different magnitudes. Improving the understanding of how costs and benefits of natural regeneration are distributed can be useful to design incentive structures that bring farmers' decision making more in line with societal benefits. This alignment is crucial for natural regeneration to fulfil its potential as a large-scale solution for pressing local and global environmental challenges.
\end{abstract}

Key words: climate change mitigation; connectivity; cost-effectiveness; ecological restoration; environment services evaluation, and incentives. 


\section{TROPICAL FORESTS ARE IRREPLACEABLE TO MAINTAIN BIODIVERSITY, PROVIDE ECOSYSTEM SERVICES} AND MITIGATE CLIMATE CHANGE AS THEY GLOBALLY HOST AROUND TWO-THIRDS OF THE SPECIES (Gardner et al. 2010) and half of the total carbon storage of the vegetation (Strassburg et al. 2010). Nonetheless, tropical forests are increasingly shrinking due to habitat loss, fragmentation and degradation as a result of the land-use change for accommodating agriculture and urban expansion (Gibbs et al. 2010). For example, between 1980 and 2012 more than 100 million ha of tropical forests were converted to other land-uses (Gibbs et al. 2010, Hansen et al. 2013). As a consequence, land-use changes may increase carbon emission, reduce sediment retention, and commit species to extinction (Foley et al. 2007, Gardner et al. 2009, Cardinale et al. 2012).

An alternative to reverse these trends is the ecological restoration of forests (Clewell \& Aronson 2007, Menz et al. 2013). Ecological restoration is the process of helping degraded or destroyed ecosystems (SER 2004). It can be done through passive (e.g., natural regeneration) or active (with human intervention) initiatives (Holl \& Aide 2011, Chazdon \& Uriarte 2016). As natural regeneration does not require human intervention, it is a cheaper initiative to increase forest cover (Birch et al. 2010). For example, in tropical regions, large scale restoration have occurred as extensive areas of secondary forest are being recovered passively due to rural-urban migration and agricultural abandonment (Guariguata \& Ostertag 2001, Aide \& Grau 2004, Bowen et al. 2007, Chazdon et al. 2009, Aide et al. 2012, Chazdon \& Guariguata 2016). In such cases, natural regeneration occurred in lands with low or no loss of income from agriculture (i.e., low opportunity cost). However, the role of these secondary regrowth forests in providing ecosystem services and facilitating biodiversity maintenance compared to old-growth forests it is an open question (Gibson et al. 2011, Lewis et al. 2015, Crouzeilles et al. 2016). Thus, to improve the cost-effectiveness of large-scale restoration, it is timely, to raise the awareness of the socioeconomic and ecological roles of natural regeneration in 
tropical forests, which remains poorly understood (Gardner et al. 2007, Chazdon et al. 2009, Chazdon \& Guariguata 2016).

A current leading scientific approach to evaluate the benefits of nature to humans is the ecosystem services framework (MEA 2005; Fisher et al. 2008, Balmford et al. 2011, IPBES 2015). Although several alternative and complementary approaches exist (IPBES 2015), the ecosystem services framework provides useful insights to estimate how ecological and socioeconomic functions interact and thus impacts human wellbeing. Natural regeneration impacts the provision of ecosystem services from the global to the local scales (Foley et al. 2007). Regrowing forests may sequester high amounts of carbon, helping to mitigate climate change (Bryan et al. 2014, Gilroy et al. 2014), and at the same time help to stabilize the soil, avoid sediment loss and improve water quality (Ditt et al. 2010).

In addition, natural regeneration also can provide suitable habitats for species (Parry et al. 2007), and increase species connectivity in the landscape (Chazdon et al. 2009). Therefore, to avoid the loss of species at the landscape scale, it is essential to maximize the amount of naturally regenerating areas available for species. Areas available for species can be measured through the habitat availability; an increasingly applied concept that consider not only the habitat amount in the landscape, but also the landscape connectivity, as even large but disconnected habitat cannot be reached and used by individuals (Saura \& Pascual-Hortal 2007, Crouzeilles et al. 2013; 2014).

In all the considerations regarding the provision of ecosystem services made above, the overall added benefit of restoration will depend on the geographical position, area size and shape of the places where natural regeneration is allowed to happen (e.g., Verhagen et al. 2016). The benefits of natural regeneration for ecosystem services and habitat availability are context specific and potentially impacted by both biophysical and socioeconomic heterogeneity across landscapes (e.g., Chazdon \& Guariguata 2016, Poorter et al. 2016).

Here we investigate the relative contribution of the natural regeneration to the provision of 
ecosystem services and biodiversity conservation in a spatially explicit manner, and discuss how this understanding can contribute to improve incentives structure that influence farmers' decision making. Our case study is in the Paraitinga basin, located in the Brazilian Atlantic Forest, one of the five hottest hotspots of conservation (Laurance 2008). To achieve these goals, we first classified the current landuse in the region using a combination of high-resolution $(5 \mathrm{~m})$ imagery and field validation. Second, we developed spatially explicit scenarios that consider potential competition for land with agriculture (Latawiec et al. 2015) and natural regeneration potential into consideration by selecting only areas of abandoned pasturelands with signs of early stage natural regeneration. Third, we quantified changes in biophysical functions related to two ecosystem services (climate change mitigation and sediment retention), and performed an economic valuation of them by comparing with the opportunity costs of the selected areas. Fourthly, we modelled possible effects of land-use changes on habitat availability for species. Finally, we discuss how incentive structures are important for natural regeneration and how these can be informed by estimates such as the ones we produced. To our knowledge, this is the first study using spatially-explicitly scenarios to inform development of financial benefits from the natural regeneration to ecosystem services, and to reveal how natural regeneration affects the relative contribution of habitat availability for species' with different dispersal ability. This study might offer useful insights to different stakeholders such as researchers, policymakers, and restoration practitioners regarding the benefits and cost-effectiveness of natural regeneration for providing ecosystem services and maintaining biodiversity.

\section{METHODS}

In this section we discuss the data inputs and the methodology used to assess the effects of natural regeneration in the functionality of the ecosystem of the Paraitinga basin, and the added economic value of a few of the services it provides. We start by describing the data images used, and the process of classification of the landscape's land-cover, which allows us to define the spatially-explicit baseline, 
and natural-regeneration scenarios. We then compute the additionality of natural regeneration with respect to the baseline in terms of sequestered carbon, sediment retention and increase of habitat availability. The transition from abandoned grassland to second-growth forest captures large quantities of carbon in the form of the increasing biomass of the vegetation, leading to an overall reduction in the amount of greenhouse gases in the atmosphere, in the natural regeneration scenario as compared to the baseline. Riparian forest areas may also contribute to sediment retention in rivers and may decrease the maintenance costs of water dredging purification for consumption. Finally, second-growth forests can connect otherwise isolated patches of remaining pristine forest, allowing for a greater number of species in those patches to increase their habitat areas, and generally the extinction debt in the landscape.

StUdy AREA AND LAND-USE/COVER CLASSIFICATION. - The Paraitinga basin is located in the State of São Paulo $(-45,6535,-23,4019 ;-44,6435,-22,7057)$, at the south-eastern coast of the Brazilian Atlantic Forest (FIGURE 1) covered by evergreen tropical forest vegetation type (see Fiaschi \& Pirani 2009). This basin (with 268,000 ha, i.e., 0,21\% of the Brazilian Atlantic Forest) has a strategic function in terms of providing water supply for São Paulo and Rio de Janeiro, two highly populated States in the Brazil. In Paraitinga basin, habitat loss and fragmentation was driven mainly by socio-economic pressures, resulting in a highly-fragmented landscape with different types of land use/cover.

To identify the main land-use/cover classes in the Paraitinga basin, we carried out a field assessment in 155 sites from 14-17 January 2014. Then, we used 12 RapidEye images (RapidEye AG 2012) from 2012, with a pixel size of $5 \mathrm{~m}$ resolution, to map the current land use/cover in a scale of 1:20,000. We used a segmentation process based on region growing approach and the Isoseg algorithm to classify the images into 12 classes, and then performed a supervised classification and rectification to correct the mapped classes. The 12 classes used were: (1) degraded areas, (2) burned areas, (3) urban areas, (4) water bodies, (5) croplands, (6) managed pastures, (7) degraded pastures, (8) abandoned 


\begin{abstract}
pastures (defined as pasture areas with presence of trees and shrubs.), (9) bare soils, (10) timber plantations (dense arboreal area with homogeneous texture), (11) secondary forests (arboreal area with heterogeneous texture), and (12) old-growth forests (dense arboreal vegetation). The supervised process was guided by a classification key, which shows land uses ground truth and its spectral response in the image. After this classification, we carried out the second field assessment in 50 sites, randomly selected along the highway that crosses the watershed, from 22-24 October 2014, to validate our final map. The map of the current land-use/cover in the region was used as the basis for all scenarios and for the evaluation of the socioeconomic and ecological impacts of the natural regeneration on ecosystem services and biodiversity conservation. All classifications were performed using the software SPRING (Câmara 1996).
\end{abstract}


LAND USE/COVER SCENARIOS.-We considered three different land use/cover scenarios to calculate the socioeconomic and ecological benefits from natural regeneration for two ecosystem services (carbon stock and sediment retention) and habitat availability for species with different dispersal abilities (Table 1). Scenario 0 represents the land cover of old-growth forests only and was used in the habitat availability analysis only. Scenario 1 is the baseline, i.e., the current land use/cover. Thus, scenarios 0 and 1 differ because the former considers old-growth forests only, while the latter considers old-growth and secondary forests. Scenario 2 simulates natural regeneration of abandoned pasture areas. These are areas with potential for natural regeneration based on biophysical/ecological and socio-economic factors. Biophysically/ecologically these areas already present signs of natural regeneration at early successional stages, while socio-economically they would present low opportunity costs. Thus, in this scenario we assumed as a premise that abandoned pasturelands would become secondary forests in 20 years. Thus, scenario 0 and 1 differs from scenario 2 because the latter assumes a land-use change in the next 20 years. For the ecosystem services of climate change mitigation and sediment retention we compared the land use/cover scenarios 1 and 2, whereas we quantified the ecological benefits of habitat availability comparing land use/cover scenarios 0,1 , and 2 . Land use/cover scenarios were modelled using the software ArcGis 9.3 (ESRI 2008). Table 1 summarizes the scenarios used in each separate analysis carried out in this work. 
ECOSYSTEM SERVICES.-Climate change mitigation. The natural regeneration of tropical forests sequester carbon dioxide from the atmosphere, which in the context of dangerous anthropogenic climate change is a very important global ecosystem service. Recent estimates suggest that this carbon sequestration potential of natural regeneration is very high (Chazdon et al. 2016). To model this climate change mitigation service, we used available data of carbon above and below the soil for each land use/cover in our map (Bernoux et al. 2006; Cardoso et al. 2012; La Scala Júnior et al. 2012; Error! Reference source not found.). We followed the approach suggested by the IPCC Good Practice Guidance for LULUCF (Penman, 2003), which is also the approach used by Brazil's National Greenhouse Gas Inventory. According to this methodology, net emissions (or sequestration) is estimated by attributing carbon stocks to different land use types, and accounting for changes in stocks based on changes in land-use. So we aggregated the carbon stock information for each pixel of the Paraitinga map in each land use/cover scenario and estimated the changes in carbon stock.

In order to estimate the economic value of the additional carbon sequestered by natural regeneration in scenario 2 , we used three values for the price of carbon and three values for discount rates, generating nine distinct estimates. For the price of carbon, we used the value currently adopted by Brazil's Amazon Fund of US\$ $5 / \mathrm{tCO}_{2}$, which is closer to current carbon prices in the absence of binding commitments, in addition to US\$10/tCO 2 and US\$ $15 / \mathrm{tCO}_{2}$, values still on the conservative to intermediate range regarding estimates for carbon prices in the coming decades (Strassburg et al. 2012). The time horizon considered in this estimate is 20 years, assuming the recovery of 10 percent of the forest every two years. This follows the time horizon profile established for environmental compliance by the Brazilian Protection of Native Vegetation Law, informally known as the 'Forest Code' (Brasil 2012). Finally, we calculated the Net Present Value (NPV) of the climate change mitigation service using a conservative discount rate of 7.5 percent per year, which is the long-term interest rate in Brazil, in addition to the more widely adopted discount rate for developing countries of 
5.0 percent and an optimistic discount rate of 2.5 percent (more in line with those found in developed countries). These analyses were performed in R 2.12 (R Core Development Core Team 2011).

Sediment Retention. The sediment retention model is directly related to the water services. The excessive soil erosion can reduce the water quality and agricultural productivity, increase flooding, and pollutant transport (Duarte et al., 2016). In relation to sediment retention, water purification is the main service provided by the forests in the study region, as the rivers are not used for navigation. In other regions, however, rivers are vital transportation networks and in that case keeping them navigable would imply additional costs that could be avoided by this same ecosystem service.

To model the sediment retention in the Paraitinga region, we used the Sediment Retention model of the software InVEST v. 3.2. The InVEST software is based on the Universal Soil Loss Equation (USLE) and estimates the potential for soil loss depending on geomorphological and climate conditions (Tallis et al., 2013).

The USLE uses information such as land use patterns, soil properties, rainfall data, and elevation to provide biophysical parameters to sediment retention model (Equation 1). The InVEST's model considers that in areas where rainfall intensity is high, there is a high chance that soil particles will be transported (Tallis et al., 2013).

Eq. $1 U S L E=R \times K \times L S \times C \times P$

Where $\mathrm{R}$ is the rainfall erosivity, $\mathrm{K}$ is the soil erodibility factor, LS is the slope length-gradient factor, $\mathrm{C}$ is the crop-management factor and $\mathrm{P}$ is the support practice factor. The result of the USLE is the annual estimation of soil loss due to water runoff, measured in tonne/hectare/year.

The InVEST model calculates directly the LS factor, yet it does not provide all the data necessary to run the model. We estimated the other USLE parameters using Geographic Information System (SIG) tools. To estimate the rainfall erosivity we used the inverse distance-weighted method to interpolate monthly and annual rainfall data from 15 meteorological stations, during 1970-2006 years. 
The Embrapa's soil map, in the scale of 1:5,000.000 was used to generate soil erodibility index. The CP factor was calculated using the land use map described above and reference data. These layers are presented in Figure 2.

The specific values used to estimate erodibility factor were obtained from reference data considering regions with the same biophysical characteristics of our study area (Machado et al. 2009, Silva et al. 2010, Goméz, 2012, Sharp et al. 2015, Duarte, 2014, Pacher, 2014, Sinisgalli et al. 2014, Sousa-Júnior, 2014; Fig. 2). To represent the elevation we used the Digital Elevation Model (DEM), in a $30 \mathrm{~m}$ resolution, from the NASA.

To evaluate the socioeconomic benefits associated with sediment retention, we obtained local values from the literature (OIKOS 2015). These values were R $\$ 0.0149$ (US\$ $0.00383 / \mathrm{m}^{3}$ ) as the regional cost of removing sediments from water in order to achieve the quality needed for domestic consumption, a usage flux of $25,00 \mathrm{~L} / \mathrm{s}$ based on actual water consumption in the region, and a density of the sediments suspended in the water of $3.04 \mathrm{ton} / \mathrm{m}^{3}$. The sediment model was applied for all 176 sub-watersheds.

We also estimated what would be the value of the sediment retention ecosystem service if the costs for dredging the river were added. In this case, we used dredging costs of US\$ 4/ton (Saad et al., 2013).

Opportunity Costs. To calculate the opportunity cost of natural regeneration, we used the land prices $(\mathrm{R} \$ /$ hectare) as a proxy for the long-term expected profit of that land (e.g., Crouzeilles et al. 2015). We used the land price values for different land uses surveyed by FNP (2015) (Error! Reference source not found.). 
Habitat availability.-To analyze the habitat availability for species with different dispersal activities in the landscape, we divided the Paraitinga region into hexagons of 10,000 ha. Only hexagons with more than 50 percent of its area inside the study area were considered in this analysis, totalling 28 hexagons (FIGURE 1). These landscape sizes, ranging from 5000 up to 10,000 ha, are consistent with previous studies that quantified the effects habitat loss and fragmentation on biodiversity in the Atlantic Forest (e.g., Crouzeilles et al. 2014, Tambosi et al. 2014).

For each landscape hexagon, we analysed the habitat availability using the Probability Connectivity index $(P C)$. This index considers the habitat amount through patch attribute (in this study patch size) and also the landscape connectivity through species response to habitat configuration (in this study the probability of species dispersal between habitat patches) (Saura \& Pascual-Hortal 2007) as follows:

$P C=\frac{\sum_{i=1}^{n} \sum_{j=1}^{n} a_{i} a_{j} p_{i j}^{*}}{A_{L}^{2}}$

where $n$ is the total number of patches, $a_{i}$ and $a_{j}$ are the patch attributes, $p_{i j}^{*}$ is the maximum product probability of all possible paths between $i$ and $j$, and $A_{L}^{2}$ is the square of the landscape area (Saura \& Rubio 2010). The probability of a path from one patch to another is the product of dispersal probabilities for all connections between these two patches. Thus, the maximum product probability is the path with highest connection probability among all possibilities between two patches. $P C$ index varies from 0 (no habitat available) to 1 (maximum habitat availability). We calculated $P C$ using the software Conefor Sensinode 2.5.8 command line version (www. conefor.org; Saura \& Torné 2009).

As habitat availability is species' specific, we estimated $P C$ considering three mean dispersal abilities (100, 1000, and $3000 \mathrm{~m}$ ) based on the review of Crouzeilles et al. (2010) for Atlantic Forest species. To represent these mean dispersal ability values, we considered a 50 percent probability of species direct dispersal between two patches, for example, a species with $100 \mathrm{~m}$ dispersal ability has 50 percent probability to cross patches that are $100 \mathrm{~m}$ apart. We used a one-way analysis of variance 


\begin{abstract}
(ANOVA) followed by the Tukey post-hoc test to identify significant differences in habitat availability among the scenarios of land use/cover for each simulated species. This analysis was performed in $\mathrm{R}$ 2.12 (R Core Development Core Team 2011).
\end{abstract}

\begin{abstract}
RESULTS
LAND-USE/COVER. - The Paraitinga basin is occupied predominantly by pastures, with $30 \%$ of the region being managed pasturelands, 21 percent degraded pasturelands and $10 \%$ abandoned pasturelands showing evidence of natural regeneration - totalling $61 \%$ of the basin area (Table 4 ). The second predominant land use is represented by old-growth forest (20.6\%), while secondary forests cover $6 \%$ of the study area. In the scenario 2 , the abandoned pastures were allowed to recover naturally, increasing the cover of secondary forest to $15.4 \%$ (Table 4 ).
\end{abstract}

ECOSYSTEM SERVICES. - Climate change mitigation. Allowing the 24,033 hectares of abandoned pastures to become secondary forests would sequester 1.68 million tonnes of carbon, or 6.18 million tonnes of $\mathrm{CO}_{2}$ (Table 5) in 20 years. The economic value of this climate change mitigation service varies from US\$ 21.2 million (US\$ 882/restored hectare) to US\$ 81.1 million (US\$ 3374/restored hectare) depending on the price of carbon and discount rate used. For an intermediate scenario (US\$ 10 per tonne of $\mathrm{CO}_{2}$ and a discount rate of 5\%), the value is US\$ 47.7 million (US\$ 1,981/restored hectare) (Table 6).

Sediment Retention. Transitioning from the current land-use to one where abandoned pasturelands are allowed regenerate (Scenario 2) would reduce sediment load into rivers by 570,000 tonnes annually (Table 7). On one extreme, dredging these sediments out of the river would cost US\$1.17 million annually, with a net present value (using a time horizon of 20 years and a discount 
rate of 5\%) of US\$ 14.61 million (US\$ 608/hectare restored). On the other hand, rivers in the region are currently not used for transportation or electricity generation, with the main direct use being household consumption. The natural regeneration of abandoned pasturelands would reduce the costs of purifying the water that is actually consumed every year by US\$ 810 per year or a NPV of US\$10.094 (US\$ 0.37 per restored hectare).

Opportunity Costs. The opportunity costs of converting abandoned pasturelands into secondary forests were conservatively estimated at US\$ 67.24 million, based on the land price per hectare for degraded pasturelands. In reality the selected areas already show signs of abandonment and it is likely that the real opportunity costs are lower than the ones estimated here.

Habitat availability. The habitat availability varied among the scenarios of land use/cover (scenarios 0, 1 and 2) and such result was affected by species dispersal ability (100, 1000 and $3000 \mathrm{~m}$ ) (Fig. 3). For species with short dispersal ability $(100 \mathrm{~m})$, all scenarios differed significantly from each other $(P=0.04$ for S0-S1 and $P<0.001$ for S0-S2 and S1-S2) (Fig. 3). Secondary forests increased substantially habitat availability in relation to old-growth forests (scenario 0 vs. scenario 1), while natural regeneration of abandoned pasturelands substantially increased habitat availability in relation to both old-growth forests only and old-growth + secondary forests (scenario 2 vs. scenario 0 and 1 , respectively). For species with intermediate and large dispersal ability (1000 and $3000 \mathrm{~m}$, respectively), only scenarios S0 and S2, and S1 and S2 differed significantly $(P<0.001$ in all cases). Thus, for these species natural regeneration in abandoned pasturelands substantially increased habitat availability in relation to both old-growth forests only and old-growth + secondary forests (scenario 2 vs. scenario 0 and 1, respectively). For species with intermediate and large dispersal abilities, there was no complementary value of secondary to old-growth forests (scenario 0 vs. 1) in terms of habitat availability for species. 


\section{DISCUSSION}

Our results show that the natural regeneration of abandoned pasturelands can improve the provision of ecosystem services and habitat availability. Over 20 years, the economic value of the two ecosystem services for which we performed economic valuation, climate change mitigation and sediment retention (US\$ 882 to US\$ 3982), can already account for 31.5-142.0 percent of the opportunity costs in the Paraitinga region. Our central estimate for the climate change mitigation service alone would account for 71 percent of the opportunity costs. In addition, secondary forests (especially for species with short dispersal ability) and natural regeneration of abandoned pasturelands can complement the value of old-growth forests in terms of habitat availability for species with different dispersal abilities.

It is broadly recognized that habitat availability increases as species' dispersal abilities increases (e.g., Saura \& Rubio 2010; Crouzeilles et al. 2013; 2014; 2015). Nonetheless, lack studies showing how species' dispersal ability affects the relative contribution of the natural regeneration to habitat availability in landscapes; the main study result we present in this paper. In the Paraitinga region, even the small naturally-regenerated forests that may arise as pasturelands are abandoned, would increase habitat availability for all species, although to different extents. Only for the less mobile species (100 m of dispersal ability) does the contribution of secondary forest significantly improve the amount of habitat availability when compared to scenario 0 (considering old-growth forests only). It suggests that those species are more strongly affected by the spatial configuration of secondary forests. Many empirical studies have shown that species with short dispersal ability are more sensitive to habitat loss and fragmentation (Awade et al. 2012; Martensen et al. 2012; Almeida-Gomes et al. 2016). It is important to highlight, however, that the dispersal ability is often correlated with home range and body size (Whitmee \& Orme 2012), which may affect the size of the minimum naturally-regenerated forest used by species, potentially impacting habitat availability.

It is also important to mention that the effects of natural regeneration could be even more 
effective if allocation were spatially optimized. In that respect, our results show the importance of planning landscape restoration in a way that maximizes the increment of habitat availability (e.g., Tambosi et al. 2014; Crouzeilles et al. 2015). Natural regeneration tends to occur in areas with low socioeconomic gains and high ecological resilience (Holl \& Aide 2011), yet it may not result in the highest increment for habitat availability. On the other hand, active restoration, if spatially planned to occur in areas with the highest benefits for habitat availability, can greatly increase the cost-effectives of this initiative. Crouzeilles et al. (2015), for example, showed that planning landscape restoration considering habitat availability can result in the strategy with the highest benefits to biodiversity per unit cost in the Brazilian Atlantic Forest. Thus, our simulations demonstrate how landscape context can affect the ecological value of the natural regenerating secondary forests for biodiversity persistence (a highlighted question by Bowen et al. 2007). It also provides insights on how to integrate land-use change modelling and habitat availability analysis - a scarce result to be found in up-to-date literature related to landscape connectivity (Ayram et al. 2015).

Spatial optimization is also important when considering scaling up forest restoration and to avoid potential displacement. Such displacement (or leakage) of agricultural production could result in pressure for deforestation in other regions (Latawiec et al. 2015). In this regard, a properly planned large-scale restoration in the Paraitinga watershed has a high potential for avoiding this issue, since the current stocking rates of pasturelands in the region range from 0.8 to 1.4 Animal Units (AU) per hectare, while the potential stoking rate can be as high as $3.79 \mathrm{AU} /$ ha (Alves-Pinto et al. in press). Increasing productivity in the region to half of the potential would be enough to spare 76 thousand hectares of pasture area for other uses (Alves-Pinto et al. in press). This means that improvement in the cattle-ranching practices alone could accommodate all the natural regeneration proposed in the scenario 2.

Our study further illustrates an important aspect about the valuation of ecosystem services: the same biophysical service can lead to very different economic values, depending exclusively on how 
beneficiaries relate to the service in question. In the Paraitinga basin, the utility of increased sediment retention as a consequence of natural regeneration of abandoned pasturelands is limited to avoiding the need for water purification for household consumption. This represents a very small fraction of the river flow, yielding a value of US\$ 0.37 per naturally-regenerated hectare. But in other basins where the rivers are used for navigation or for hydroelectric power, the economic value of this service could reach as high as US\$ 608 per restored hectare.

Our results can also help in designing a payment for ecosystem services (PES) scheme. One key element is the spatial distribution patterns of sources of services and the associated beneficiaries, which should inform the allocation of incentives and costs of PES schemes. It can also suggest the potential of different ecosystem services to finance a PES scheme. In the case analyse don this study, although the potential for such a scheme based on local ecosystem services might be relatively low, there is a very high potential for such a scheme based on the global ecosystem service of climate change mitigation (Tables $5 \& 6$ ). Therefore, our results reinforce recent outcomes that demonstrated the potential of secondary forests in the Neotropics for carbon sequestration (Poorter et al. 2016) and, as a consequence contribute to climate change mitigation (Chazdon et al. 2016). Such a scheme could provide important incentives for natural regeneration in the region.

The incentives to which a farmer is exposed, however, goes beyond direct and explicit financial incentives. The revised version of the Brazilian 'Forest Code' will make public agricultural credit conditional to environmental compliance with the Forest Code. Among other requirements, the Forest Code demands that farmers in the Atlantic Forest restore and/or preserve 20 percent of their farm's total area as Legal Reserve, also including Areas of Permanent Preservation (APP's) that considers riparian areas, hilltop and steep slopes (Brancalion et al. 2016, Latawiec et al. 2016). Recent estimates suggest that up to six million hectares would need to be restored in the Atlantic Forest alone (SoaresFilho et al. 2014). Farmers must provide plans for restoring their possible forest deficits but active ecological restoration (e.g., complete planting) in the country is costly, estimated around US\$ 
5150.00/ha, involving seedling acquisition, replanting and monitoring (Rodrigues et al. 2011). If an area equivalent to the abandoned pastures was actively restored, instead of naturally regenerated, it would cost US\$ 124 million. Therefore, natural regeneration may offer a cheaper alternative to comply with the Forest Code, and have a positive impact on the provision of ecosystem services in the region.

A related important aspect when designing incentive schemes is that unintended consequences of 'positive' incentives should always be taken into account. For instance, natural regeneration was suppressed in the Atlantic Forest when the Atlantic Rainforest Law (Brasil 2006) was introduced. The Law prohibited the clearing of areas on which intermediate natural regeneration was observed. Although intended to help to foster natural regeneration, an unintended result was that the farmers started regularly burn the initial stages of naturally-regenerating areas in order to avoid losing the right to use that land as pasture or croplands. Similar examples can be found elsewhere (Román-Dañobeytia et al. 2014).

In this study we included some elements of uncertainty in our estimation of climate change mitigation service (by using different prices of carbon and discount rates). Future studies could include improved treatment of uncertainties associated with the biophysical and socioeconomic processes involved.

\section{CONCLUSIONS}

Natural regeneration provides a range of benefits to human societies and it may play a key role if ambitious global and national restoration targets (e.g., the New York Declaration on Forests and Atlantic Forest Pact, respectively) are realized (e.g., Chazdon et al. 2016). Our analysis shows the importance of improving the understanding of costs and benefits of restoration, especially natural regeneration, and showed how this can affect the provision of ecosystem services and biodiversity conservation in a spatially-explicit model. The biodiversity conservation cannot be properly valued in financial terms as its main benefit is providing the ecological base for all the other ecosystem services, 
e.g., through species seeds dispersal. But an improved understanding of current and potential incentive structures, financially explicit, is crucial to ecosystem services, so that societal benefits can be better aligned with those of the final decision maker, the farmer. This alignment is essential for natural regeneration to realize its promise of providing cost-effective benefits to nature and human societies at large scales. 


\section{LITERATURE CITED}

Almeida-Gomes M., Prevedello J.A., \& Crouzeilles R. 2016. The use of native vegetation as a proxy for habitat may overestimate habitat availability in fragmented landscapes. Landscape Ecology. 31: 711-719.

ALVES-PINTO, H. StRASSBURG, B. B. N., LATAWIEC, A., BARROS, F. S., RANGEL, M. C., SANSEVERO, J. B. B., IRRIBAREM, A., BARBIERI, R. F., LEMGRUBER, L, Conciliating rural development and ecological restoration: strategies and policy recommendations for the Brazilian Atlantic Forest. Land Use Policy, in press.

ARONSON J AND AlEXANDER S. 2013. Ecological restoration is now a global priority: time to roll up our sleeves. Restor Ecol 21:293-96.

Awade M, Boscolo D, MetzGer JP (2012) Using binary and probabilistic habitat availability indices derived from graph theory to model bird occurrence in fragmented forests. Landscape Ecol $27: 185-198$

Ayram C.A.C, Mendoza M.E., EtTer A., \& Salicrup D.R.P. 2015 Habitat connectivity for conservation - a review of recent studies. Progress in Physical Geography. DOI: $10.1177 / 0309133315598713$

Baillie, J.E.M., Hilton-Taylor C., Stuart S.N. (eds.) 2004. 2004 IUCN Red List of Threatened Species. A Global Species Assessment. Gland: IUCN.

BERNOUX, M., CERRI, C. C., CERRI, C. E. P., NETO, M. S., METAY, A., PERRIN, A-S., SCOPEL, E., TANTEly, R., BlAVET, D., PICCOLO, M.. C., PAVEI, M., MILNE, E. 2006. Crooping systems, carbon sequestration and erosion in Brazil: a review. Agron. Sustain. 26: 1-8.

Bowen, M. E., McAlpine, C. A., House, A. P. N. \& Smith, G. C. 2007. Regrowth forests on abandoned agricultural land: A review of their habitat values for recovering forest fauna. Biol. 
Conserv. 140, 273-296.

Bowen, M.E., McAlpine, C.A., House, A.P.N. \& SMith, G.C. (2007) Regrowth forests on abandoned agricultural land: a review of their habitat values for recovering forest fauna. Biological Conservation, 140, 273-296.

Brancalion, P., D. Schweizer, U. Gaudare, J. Mangueira, F. Lamonato, F. Farah, . . . R. RODRIGUES. 2016. Balancing economic costs and ecological outcomes of passive and active restoration in agricultural landscapes: the case of Brazil. . Biotropica 48.

BRASIL. 2012. Lei número 12,651 15 de maio, 2012. Regulamento da Proteção da vegetação nativa. Electronic Database accessible at http://www.planalto.gov.br/ccivil_03/_ato20112014/2012/lei/112651.htm

Cardinale BJ, Duffy JE, Gonzalez A, et al. 2012. Biodiversity loss and its impact on humanity. Nature 486: 59-67.

CARDOSO, D. J.; GARRASTAZU, M. C.; LACERDA, A. E. B. DE; HIGA, R. C. V.; ROSOT, M. A. D. 2012. Avaliação das variáveis e disponibilidade de informações do modelo de estoque de carbono do aplicativo InVEST. Embrapa Electronic Database accessible at https://www.embrapa.br/busca-de-publicacoes/-/publicacao/934758/avaliacao-das-variaveis-e$\underline{\text { disponibilidade-de-informacoes-do-modelo-de-estoque-de-carbono-do-aplicativo-invest }}$

Chazdon, R. L. (2008). Beyond deforestation: restoring forests and ecosystem services on degraded lands. Science (New York, N.Y.), 320(5882), 1458-1460. http://doi.org/10.1126/science.1155365

Chazdon, R. L., E. N. Broadbent, D. M. A. Rozendahl, F. Bongers, A. M. A. Zambrano, T. M. Aide, ... L. PoORTER. 2016. Carbon sequestration potential of second-growth forest regeneration in the Latin American tropics. Science Advances 2: e1501639.

Chazdon, R. L., And M. R. Guariguata. 2016. Natural regeneration as a tool for large-scale forest Association for Tropical Biology and Conservation 
restoration in the tropics: prospects and challenges Biotropica 48: $\mathrm{xxx}-\mathrm{xxx}$.

Chazdon, R. L., C. A. Peres, D. Dent, D. Sheil, A. E. Lugo, D. Lamb, . . . S. E. Miller. 2009. The potential for species conservation in tropical secondary forests. Conservation Biology 23: 14061417.

Chazdon, R. L., AND M. URiarte. 2016. Natural regeneration in the context of large-scale forest and landscape restoration in the tropics. Biotropica 48: $\mathrm{xxx}-\mathrm{xxx}$.

Crouzeilles R, Lorini ML, Grelle CEV 2010. Deslocamento na matriz para espécies da Mata Atlântica e a dificuldade da construção de perfis ecológicos. Oecologia Australis 14:875-903

Crouzeilles R, LORINi ML, Grelle CEV 2013. The importance of using sustainable use protected areas for functional connectivity. Biological Conservation 159:450-457.

Crouzeilles R, Prevedello JA, Figueiredo MSL, Lorini ML, Grelle CEV 2014. The effects of the number, size and isolation of patches along a gradient of native vegetation cover: how can we increment habitat availability? Landscape Ecol 29:479-489.

Crouzeilles R., Curran M., Ferreira M.S., Lindenmayer D.B., Grelle C.E.V. \& Rey Benayas J.M. 2016. A global meta-analysis on the ecological drivers of forest restoration success. Nature Communications. DOI: 10.1038/ncomms 11666

Crouzeilles, R., Beyer, H.L., Mills, M., Grelle, C.E.V. \& Possingham, H.P. 2015. Incorporating habitat availability into systematic planning for restoration: a species-specific approach for Atlantic Forest mammals. Diversity and Distributions, 21, 1027-1037

Ditt, E., S. Mourato, J. Ghazoul, and J. KNigth. 2010. Forest conversion and provision of ecosystem services in the Brazilian Atlantic forest. L. Degrad. Dev. 603: 591-603. Available at: http://onlinelibrary.wiley.com/doi/10.1002/ldr.1010/full [Accessed January 7, 2014]. 
DUARTE, G. T. 2014. Ecosystem services modeling as a tool for defining priority areas for conservation. MSc. Dissertation, Universidade Federal de Minas Gerais, Belo Horizonte, Brazil.

ESRI 2008. ArcView 9.3. Redlands, California, USA.

FiASCHI, P., and J. R. PIRANI. 2009. Review of plant biogeographic studies in Brazil. J. Syst. Evol. 47: 477-496. Available at: http://doi.wiley.com/10.1111/j.1759-6831.2009.00046.x [Accessed May $22,2013]$

FOLEY JA ET al. 2007 Amazonia revealed: forest degradation and loss of ecosystem goods and services in the Amazon Basin. Front. Ecol. Environ. 5, 25-32. (doi:10.1890/1540-9295(2007)5[25: ARFDAL]2.0.CO;2)

Gardner tA, Barlow J, Chazdon R, Ewers RM, Harvey CA, Peres CA, Sodhi NS. 2009 Prospects for tropical forest biodiversity in a human-modified world. Ecol. Lett. 12, 561-582. (doi:10.1111/j.1461-0248.2009.01294.x)

GARdner TA, BArlow J, Sodhi NS, Peres CA. 2010 A multi-region assessment of tropical forest biodiversity in a human-modified world. Biol. Conserv. 143, 2293-2300. (doi:10.1016/j.biocon.2010.05.017)

Gardner, T. A., J. Barlow, L. W. Parry, and C. A. Peres. 2007. Predicting the uncertain future of tropical forest species in a data vacuum. Biotropica 39: 25-30.

Gibbs HK, Ruesch AS, Achard F, Clayton MK, Holmgren P, Ramankutty N, Foley JA. 2010 Tropical forests were the primary sources of new agricultural land in the 1980s and 1990s. Proc. Natl Acad. Sci. USA 107, 16 732-16 737. (doi:10.1073/pnas.0910275107

GOMÉZ, J. D. P. 2012. Estimativa de erosão pela equação universal de perda de solo (USLE)e transferência de sedimentos para todo território brasileiro. 2012. MSc. Dissertation. Universidade de São Paulo, Escola Superior de Agricultura "Luiz de Queiroz". Piracicaba, Brazil. 
GREENWOOD, N. N., EARNSHAW, A. 1997. Chemistry of the Elements. Butterworth - Heinemann. Oxford, Amsterdam, Boston, London, New York, Paris, San Diego, San Francisco, Singapore, Sydney, Tokyo.

Guariguata, M. R., \& Ostertag, R. (2001). Neotropical secondary forest succession: Changes in structural and functional characteristics. Forest Ecology and Management, 148(1-3), 185-206. http://doi.org/10.1016/S0378-1127(00)00535-1

Hansen, M. C., Potapov, P. V, Moore, R., Hancher, M., Turubanova, S. A, Tyukavina, A., Townshend, J. R. G. (2013). High-resolution global maps of 21st-century forest cover change. Science (New York, N.Y.), 342(6160), 850-3. http://doi.org/10.1126/science.1244693

JOERN FISCHER, \& LINDENMAYER, AND D. B. (2007). Landscape modification and habitat fragmentation: a synthesis. Global Ecology and Biogeography, 1-16. http://doi.org/10.1111/j.1466-8238.2006.00287.x

LA SCALA JÚNIOR, N., DE FIGUEIREDO, E. B. PANOSO, A. R. A review on soil carbon accumulation due to the management change of major Brazilian agricultural activities. 2012. Braz. J. Biol. 72: 775-785.

Latawiec, A. E., R. Crouzeilles, P. H. S. Brancalion, R. R. Rodrigues, J. B. B. Sansevero, J. S. dos Santos, ... B. B. N. Strassburg. 2016. Natural regeneration and biodiversity: a global meta-analysis and implications for spatial planning. Biotropica 48: xxx-xxx.

MACHADO, M. L., AlVES, J. S., GOMES, I., VIEIRA, E. M., SIMÃO, M. L. R., NAIME, U. J. Levantamento sistemático dos fatores da equação universal de perdas de solo (USLE) para o delineamento de áreas com potencial erosivo da bacia PN1-IGAM, Minas Gerais (resultados parciais). In: SIMPÓSIO BRASILEIRO DE SENSORIAMENTO REMOTO, 14. (SBSR), 2009, Natal. Anais... São José dos Campos: INPE, 2009. p. 7733-7739. DVD, On-line. ISBN 978-85- 
Martensen AC, Ribeiro MC, Banks-Leite C, Prado PI, MetzGer JP (2012) Associations of forest cover, fragment area, and connectivity with Neotropical understory bird species richness and abundance. Cons Biology 26:1100-1111

Myers, N., Mittermeier, R. A., Mittermeier, C. G., da Fonseca, G. A. B., \& Kent, J. (2000). Biodiversity hotspot for conservation priorities. Nature, 403(6772), 853-858. $\underline{\text { http://doi.org/10.1038/35002501 }}$

OIKOS 2015. Projeto PSA Água Vale do Paraíba. Available at: http://institutooikos.org.br/projetos/DOCUMENTOFINALPSAAGUAVALEDOPARAIBA.pdf [Accessed November 5, 2015]

Oliveira-Filho, A., AND M. Fontes. 2000. Patterns of Floristic Differentiation among Atlantic Forests in Southeastern Brazil and the Influence of Climate. Biotropica 32: 793-810. Available at: http://onlinelibrary.wiley.com/doi/10.1111/j.1744-7429.2000.tb00619.x/abstract [Accessed August 16, 2014].

PACHER, G. V. 2014. Avaliação de áreas prioritárias para pagamento por serviços ambientais de proteção de solos na bacia do rio Paraíba do sul em São Paulo. MSc. Dissertation. Instituto Tecnológico da Aeronáutica, São José dos Campos, Brazil.

POORTER, L. ET AL. 2016. Biomass resilience of Neotropical secondary forests. Nature 530: 211-214. Available at: http://www.nature.com/doifinder/10.1038/nature16512.

R Core Development Core TEAm. (2011) R: a language and environment for statistical computing. R Foundation for Statistical Computing. http://www.R-project.org

RAPIDEYE AG (2012). Satellite imagery product specifications [online]. Available from: www.rapideye.net/upload/RE_Product_Specifications_ENG.pdf [accessed: 24-05-2012]. 
Román-Dañobeytia, F. J., S. I. LeVy-Tacher, P. Macario-Mendoza And J. ZúÑiga-Morales (2014). "Redefining secondary forests in the Mexican Forest Code: Implications for management, restoration, and conservation." Forests 5(5): 978-991.

SAURA, S. AND PASCUAL-HORTAL, L. 2007. A new habitat availability index to integrate connectivity in landscape conservation planning: comparison with existing indices and application to a case study. Landscape and Urban Planning 83 (2-3): 91-103.

SAURA, S. AND RUBIO, L. 2010. A common currency for the different ways in which patches and links can contribute to habitat availability and connectivity in the landscape. Ecography 33: 523-537.

SAURA, S. AND TORnÉ, J. 2009. Conefor Sensinode 2.2: a software package for quantifying the importance of habitat patches for landscape connectivity. Environmental Modelling Software 24: 135-139.

SHARP, R., TALLIS, H.T., RICKETTS, T., GUERRY, A.D., WOOD, S.A., CHAPLIN-KRAMER, R., NELSON, E., ENNAANAY, D., WOLNY, S., OLWERO, N., VIGERSTOL, K., PENNINGTON, D., MENDOZA, G., AUKEMA, J., FOSTER, J., FORREST, J., CAMERON, D., ARKEMA, K., LONSDORF, E., KENNEDY, C., VERUTES, G., KIM, C.K., GUANNEL, G., PAPENFUS, M., TOFT, J., MARSIK, M., BERNHARDT, J., GRIFFIN, R., GLOWINSKI, K., CHAUMONT, N., PERELMAN, A., LACAYO, M. MANDLE, L., HAMEL, P., VOGL, A.L., ROGERS, L., AND BIERBOWER, W. 2015. InVEST +VERSION+ User's Guide. The Natural Capital Project, Stanford University, University of Minnesota, The Nature Conservancy, and World Wildlife Fund.

Silva, F. G. B, MinotTi, R. T., NETO, F. L., PRIMAVESI, O., CRESTANA, S. Loss of soil determination in fazenda Canchim - SP (Embrapa) using geographic information systems and USLE 2D. 2010. Eng. Sanit. Ambient. 15: 141-148. 
SINISGALLI, P., BUENO, A. K., FERNANDES, V. B. 2014. Pesquisa sobre a dinâmica dos mercados de terras de São Luís do Paraitinga: subsídios para o cálculo de pagamento por serviços ambientais. Relatório de Pesquisa.

SoAres-Filho, B., R. RajÃO, AND M. MaCEdo. 2014. Cracking Brazil's Forest Code. Science (80-. ). 344: 363-364. Available at: http://www.spde.org/documentos/noticias/Science-2014-SoaresFilho-363-4.pdf [Accessed July 12, 2014].

SOUSA-JÚNIOR, W. C., RIBEIRO, T., PACHER, G. V., PAVANI, B. F. 2014. Pagamento por serviços ambientais nos mananciais da bacia do rio Paraíba do sul, SP. Relatório de Pesquisa.

StrassburG, B. B. N., LATAWIEC, A., PENTEAdO, M., STONER, L. A., BARROS, F. S., RANGEL, M. C., SANSEVERO, J. B. B., IRRIBAREM, A., BARBIERI, R. F., ALVES-PINTO H., RESENDE, F., LEMGRUBER, L, 2015. Análise integrada do uso da terra e de incorporação dos serviços ecossistêmicos na formulação de políticas regionais - Bacia do Rio Paraitinga - São Paulo. Relatório de pesquisa.

TOPODATA, 2015. Banco de dados geomorfométricos do Brasil. Electronic Database accessible at $\underline{\text { http://www.webmapit.com.br/inpe/topodata/ }}$

Verhagen W, Van Teeffelen Aja, Compagnucci AB, Poggio L, Gimona A, Verburg PH (2016) Effects of landscape configuration on mapping ecosystem service capacity: a review of evidence and a case study in Scotland. Land Ecol 31:1457-1479.

Whitmee S, ORMe CDL (2012) Predicting dispersal distance in mammals: a trait-based approach. J Anim Ecol DOI: 10.1111/j.1365-2656.2012.02030.x

Wright, S. J., And H. C. Muller-Landau. 2006. The future of tropical forest species. Biotropica $38: 287-301$. 


1
2
3
4
5
6
7
8
9
10
11
12
13
14
15
16
17
18
19
20
21
22
23
24
25
26
27
28
29
30
31
32
33
34
35
36
37
38
39
40
41
42
43
44
45
46
47
48
49
50
51
52
53
54
55
56
57
59
60


TABLE 1. Description of the three land use/cover scenarios

\begin{tabular}{|c|c|c|c|}
\hline Spatial layer / analysis & $\begin{array}{r}\text { Scenario } 0 \\
\text { Old growth forests } \\
\text { only }\end{array}$ & $\begin{array}{r}\text { Scenario } 1 \\
\text { Current land-cover }\end{array}$ & $\begin{array}{r}\text { Scenario } 2 \\
\text { Natural regeneration in } \\
\text { abandoned pasturelands }\end{array}$ \\
\hline Old-growth forests & Included & Included & Included \\
\hline Secondary forests & Not included & Included, current & $\begin{array}{l}\text { Included, current }+ \\
\text { abandoned pasturelands }\end{array}$ \\
\hline Abandoned pastures & $\begin{array}{r}\text { Remains } \\
\text { abandoned }\end{array}$ & Remains abandoned & Becomes secondary forests \\
\hline Habitat availability & Performed & Performed & Performed \\
\hline Carbon Stocks & Not Performed & Performed & Performed \\
\hline Sediment retention & Not Performed & Performed & Performed \\
\hline
\end{tabular}


TABLE 2. Carbon stock in each land use/cover (tonne/hectare) in the Paraitinga region, at the Brazilian Atlantic Forest.

\begin{tabular}{lllllc}
\hline Land use description & Above & Below & Soil & Dead & Total (t/ha) \\
\hline Degraded areas & 0 & 0 & 0 & 0 & - \\
Burned areas & 0 & 0 & 0 & 0 & - \\
Urban areas & 15 & 3.8 & 41 & 0 & 60 \\
Water & 0 & 0 & 0 & 0 & - \\
Croplands & 7.2 & 1.9 & 62.44 & 1.1 & 73 \\
Secondary forests & 69 & 13.2 & 90.6 & 3.6 & 176 \\
Old-growth forests & 134 & 27.6 & 90.6 & 3.6 & 256 \\
Managed pastures & 2.9 & 7.7 & 94.6 & 1.1 & 106 \\
Degraded pastures & 2.9 & 7.7 & 94.6 & 1.1 & 106 \\
Abandoned pastures & 2.9 & 7.7 & 94.6 & 1.1 & 106 \\
Timber plantations & 56.7 & 9.9 & 74.3 & 7.4 & 148 \\
Bare soils & 0 & 0 & 0 & 0 & - \\
\hline
\end{tabular}


TABLE 3. Land prices (per hectare) in Paraitinga region, at the Brazilin Atlantic Forest. These prices are expressed considering the exchange rate in 18 December 2015 (US\$ $1=\mathrm{R} \$ 3.89$ ) and where obtained from FNP (2015).

\begin{tabular}{lcc}
\hline Land use & R\$ & US\$ \\
\hline Crops & 26,333 & 6,769 \\
Pastures & 11,992 & 3,083 \\
Degraded and abandoned pastures & 10,883 & 2,798 \\
Timber plantations and others & 14,860 & 3,820 \\
\hline
\end{tabular}

3

4

5

6

7

8

9

10

11

12

13

14

15

16

17

18

19

20

21

22

23

24

25

26

27

28

29

30

31

32

33

34

35

36

37

38

39

40

41

42

43

44

45

46

47

48

49

50

51

52

53

54

55

56

57

58

59

60 
TABLE 4. Current land use (S1) and land use if abandoned pastures recover naturally to secondary forests (S2).

\begin{tabular}{lllll}
\hline & & & & \\
Land use description & S1 (hectares) & S1 (\%) & S2 (hectares) & S2 (\%) \\
\hline & & & & \\
Degraded areas & 5,120 & $2.1 \%$ & 5,120 & $2.1 \%$ \\
Burned soils & 5,727 & $2.4 \%$ & 5,727 & $2.4 \%$ \\
Urban areas & 492 & $0.2 \%$ & 492 & $0.2 \%$ \\
Water & 3,416 & $1.4 \%$ & 3,416 & $1.4 \%$ \\
Crops & 80 & $0.0 \%$ & 80 & $0.0 \%$ \\
Secondary forests & 13,165 & $5.5 \%$ & 37,198 & $15.4 \%$ \\
Old-growth forests & 46,025 & $19.1 \%$ & 46,025 & $19.1 \%$ \\
Managed pastures & 75,372 & $31.2 \%$ & 75,372 & $31.2 \%$ \\
Degraded pastures & 51,646 & $21.4 \%$ & 51,646 & $21.4 \%$ \\
Abandoned pastures & 24,034 & $10.0 \%$ & - & $0.0 \%$ \\
Timber plantations & 15,663 & $6.5 \%$ & 15,663 & $6.5 \%$ \\
Bare soils & 686 & $0.3 \%$ & 686 & $0.3 \%$ \\
Total & $\mathbf{2 4 1 , 4 2 5}$ & & $\mathbf{2 4 1 , 4 2 5}$ & \\
& & & &
\end{tabular}


TABLE 5. Carbon stocks (in tonne/carbon) for scenarios 1 and 2, and the change from the scenario 1 to the scenario 2 .

\begin{tabular}{lccc}
\hline Land use & Carbon Stock (S1)(tC) & Carbon Stock (S2)(tC) & Change (S2-S1)(tC) \\
\hline Degraded areas & - & - & - \\
Burned soils & - & - & - \\
Urban areas & 29,440 & 29,440 & - \\
Water & - & - & - \\
Crops & 5,786 & 5,786 & - \\
Secondary forests & $2,322,230$ & $6,561,773$ & $4,239,543$ \\
Old-growth forests & $11,773,198$ & $11,773,198$ & - \\
Managed pastures & $8,012,056$ & $8,012,056$ & - \\
Degraded pastures & $5,489,937$ & $5,489,937$ & - \\
Abandoned pastures & $2,554,781$ & & - \\
Timber plantations & $2,322,872$ & $2,322,872$ & $-2,554,781$ \\
Bare soils & - & - & - \\
Total & $\mathbf{3 2 , 5 1 0 , 2 9 9}$ & $\mathbf{3 4 , 1 9 5 , 0 6 1}$ & - \\
\hline
\end{tabular}


TABLE 6. Economic value of the climate change mitigation service, under different assumptions.

\begin{tabular}{|c|c|c|c|}
\hline Discount Rate & $\left(@ 5 \mathrm{US} / \mathrm{t} \mathrm{CO}_{2}\right)$ & $\left(@ 10 \mathrm{US} \$ / \mathrm{t} \mathrm{CO}_{2}\right)$ & $\left(@ 15 \mathrm{US} / \mathrm{t} \mathrm{CO}_{2}\right)$ \\
\hline $7.5 \%$ & $21,201,291$ & $42,402,582$ & $63,603,873$ \\
\hline $5.0 \%$ & $23,850,352$ & $47,700,704$ & $71,551,057$ \\
\hline $2.5 \%$ & $27,032,760$ & $54,065,520$ & $81,098,280$ \\
\hline
\end{tabular}


TABLE 7. Sediment retention and export.

\begin{tabular}{|c|c|c|c|}
\hline & S1 & $\mathbf{S 2}$ & Difference \\
\hline \multicolumn{4}{|c|}{ Total tons of sediment (Mton. / year) } \\
\hline Retention & 52.03 & 52.60 & 0.57 \\
\hline \multicolumn{4}{|c|}{ Total value for water purification service (US\$) } \\
\hline Retention & 927,440 & 937,530 & 10,094 \\
\hline \multicolumn{4}{|c|}{ Area value for water purification service (US\$/hectare) } \\
\hline Retention & $\mathrm{n} / \mathrm{a}$ & $\mathrm{n} / \mathrm{a}$ & 0.37 \\
\hline \multicolumn{4}{|c|}{ Total value for navigability services (million US\$) } \\
\hline Retention & $1,333.49$ & $1,348.10$ & $14,608.66$ \\
\hline \multicolumn{4}{|c|}{ Area value for navigability services (US\$/hectare) } \\
\hline Retention & $\mathrm{n} / \mathrm{a}$ & $\mathrm{n} / \mathrm{a}$ & 607.84 \\
\hline
\end{tabular}


FIGURE 1. Location and land-use/cover classes used in the following analysis for the Paraitinga region, in the State of São Paulo, at the Brazilian Atlantic Forest. The hexagons represent different landscapes for the analysis of habitat availability (see this section below).

FIGURE 2. Maps of the land-use, elevation using the digital elevation model (DEM), rainfall erosivity and soil erodibility required to calculate the Universal Soil Loss Equation (USLE) for the sediment retention model in the software InVEST.

FIGURE 3. Habitat availability for species with short $(100 \mathrm{~m})$, intermediate $(1000 \mathrm{~m})$ and large $(3000$ m) dispersal ability in the different scenarios of land use/cover. Current old-growth forests only (Scenario $0-a)$, current land use (Scenario $1-b)$ and land use if abandoned pastures recover naturally to secondary forests (Scenario $2-\mathrm{c})$. 


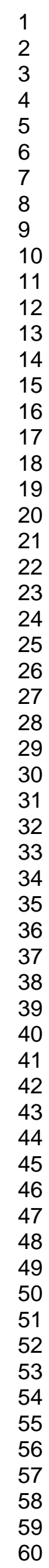

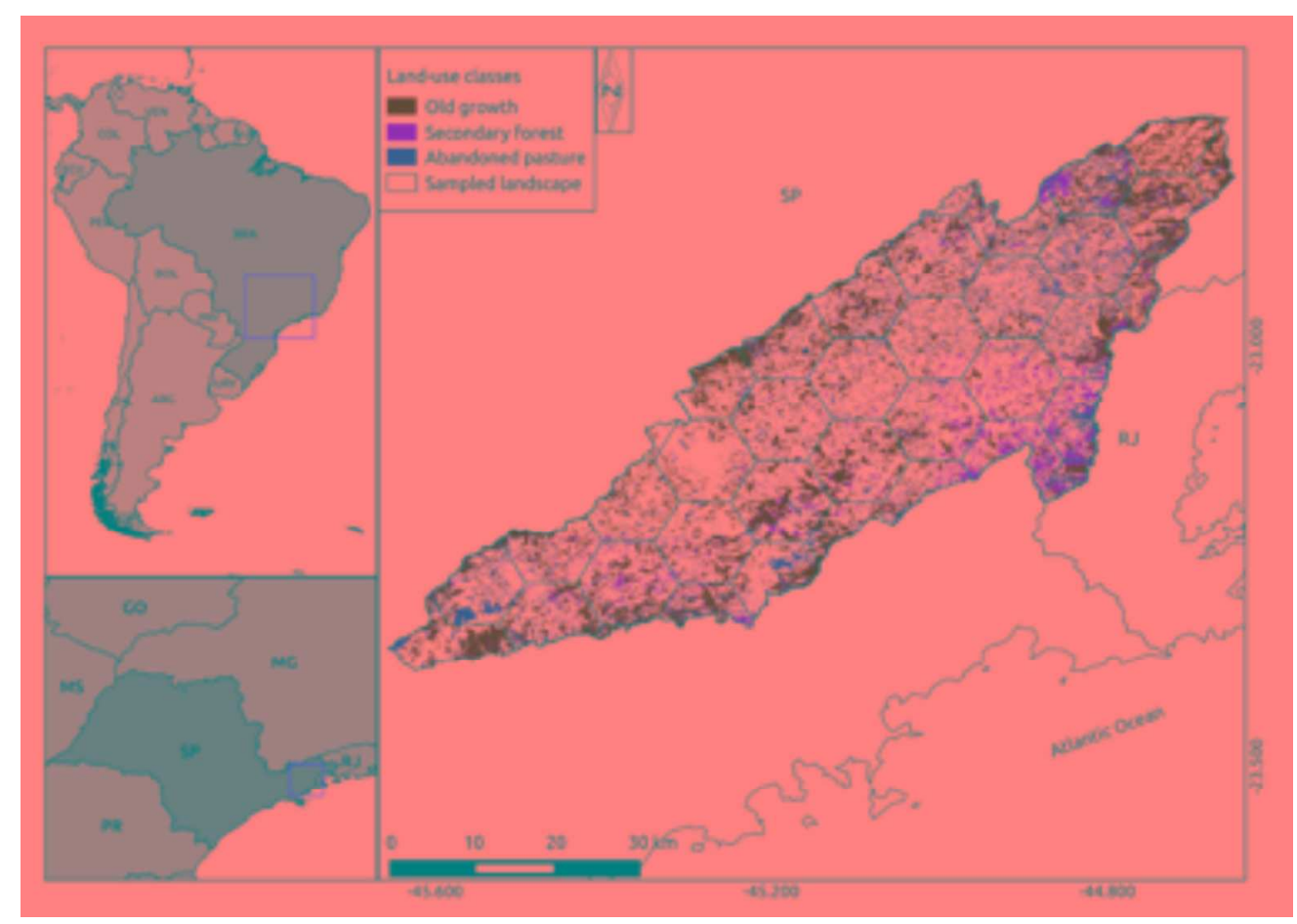

$134 \times 95 \mathrm{~mm}(300 \times 300 \mathrm{DPI})$ 


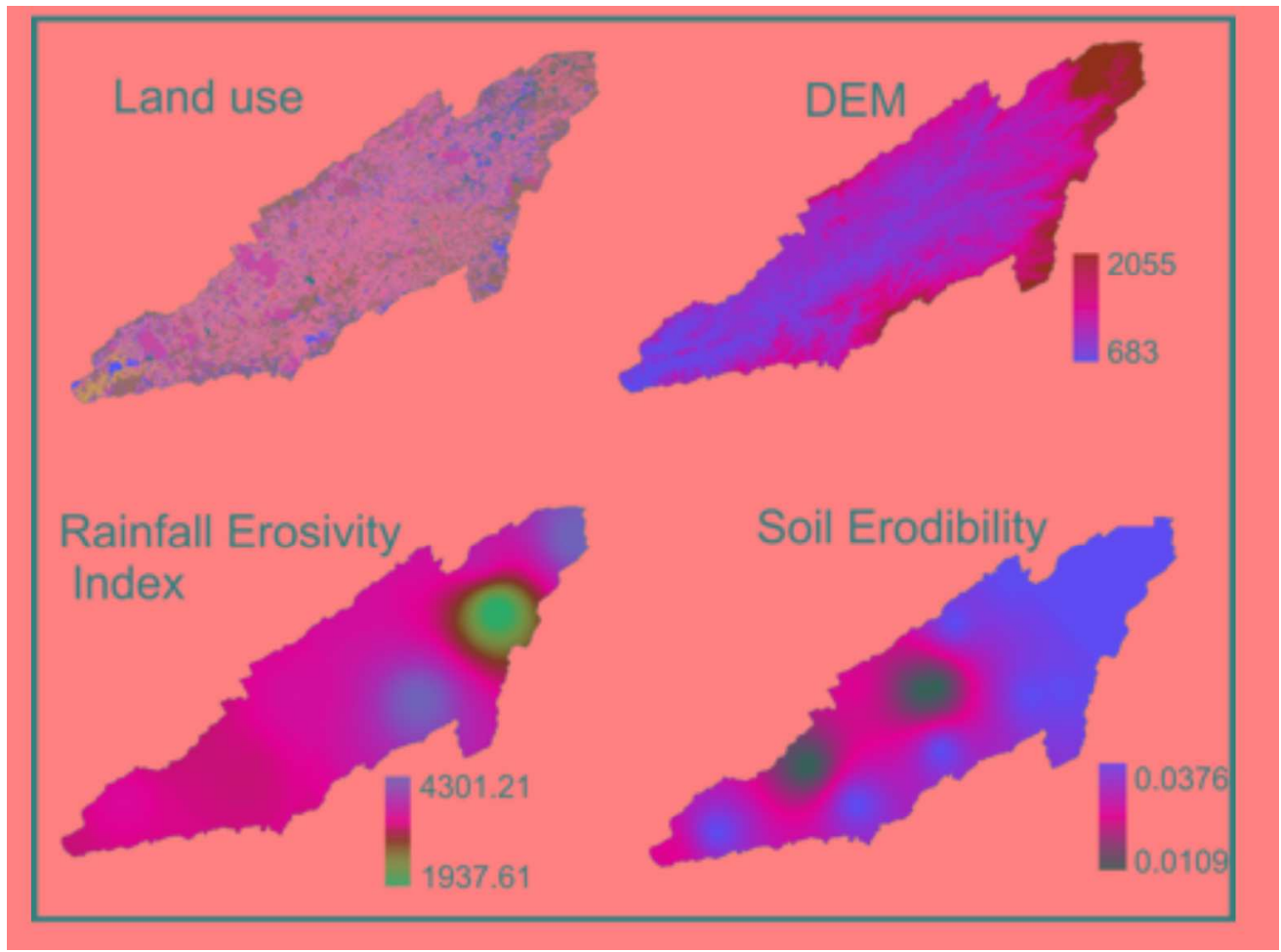

$158 \times 117 \mathrm{~mm}(300 \times 300 \mathrm{DPI})$ 


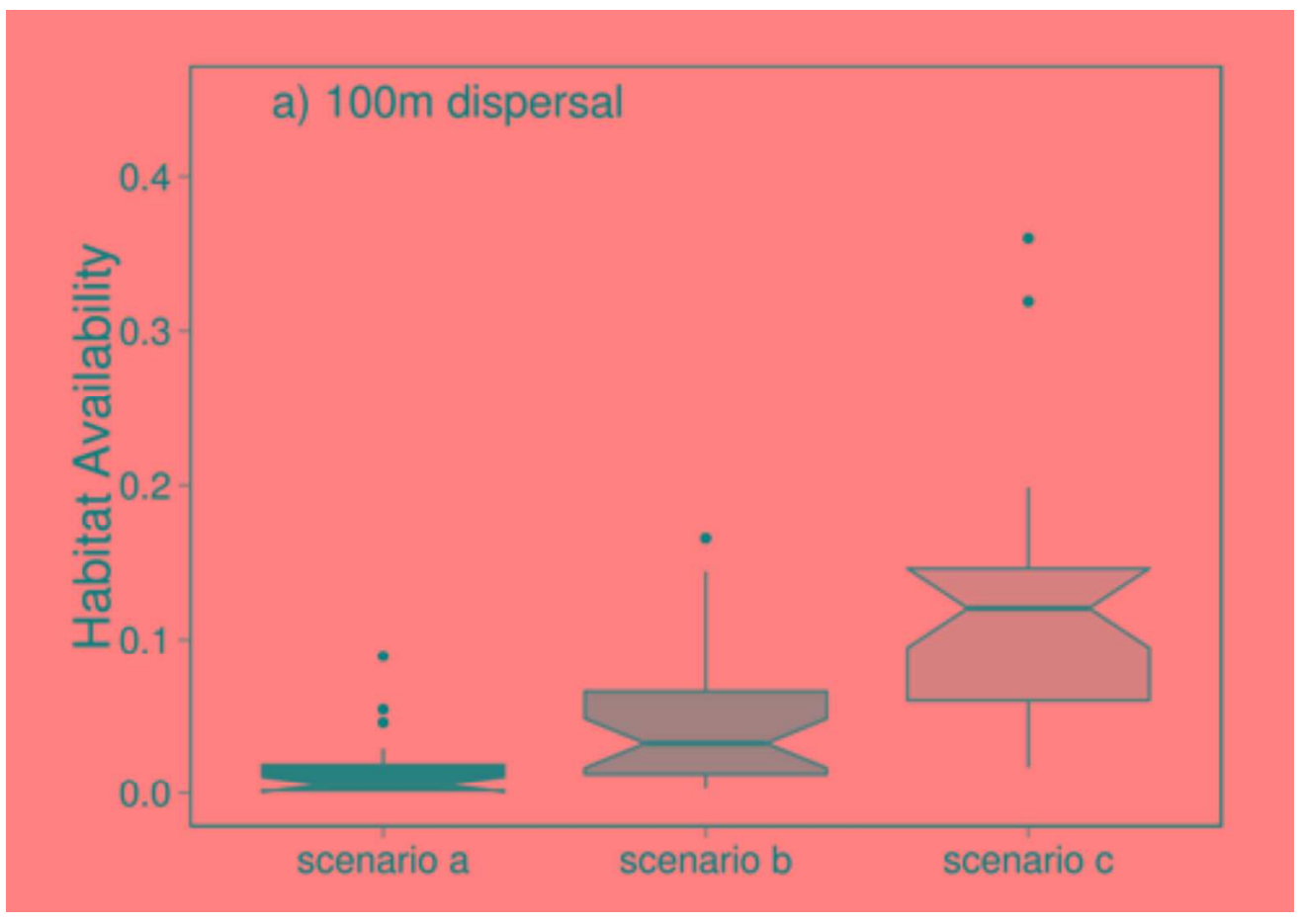

$175 \times 122 \mathrm{~mm}(300 \times 300 \mathrm{DPI})$ 


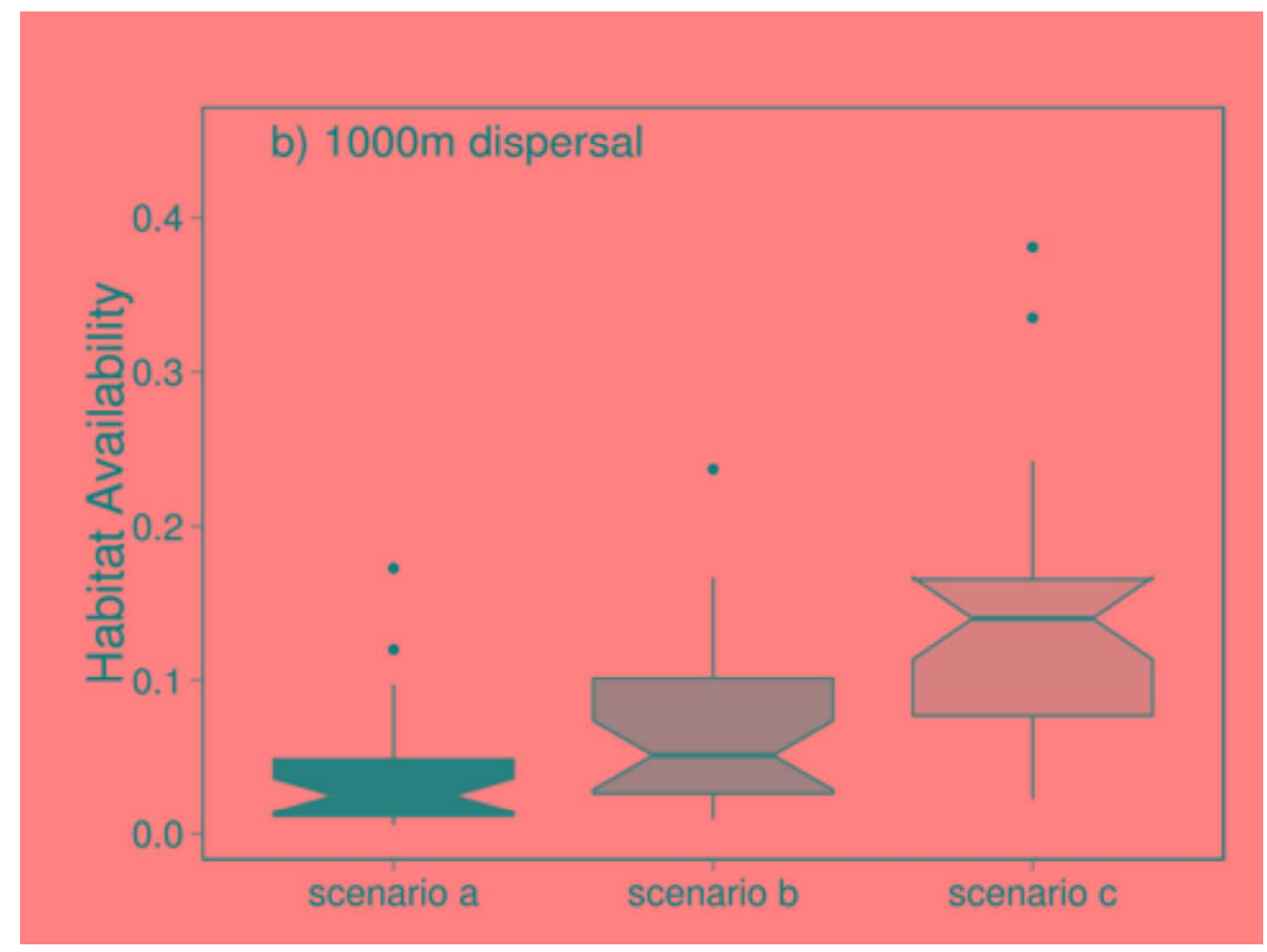

$171 \times 128 \mathrm{~mm}(300 \times 300$ DPI $)$ 


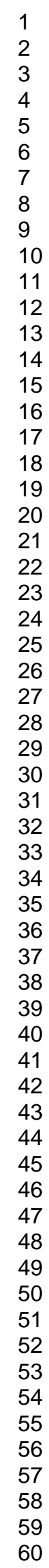

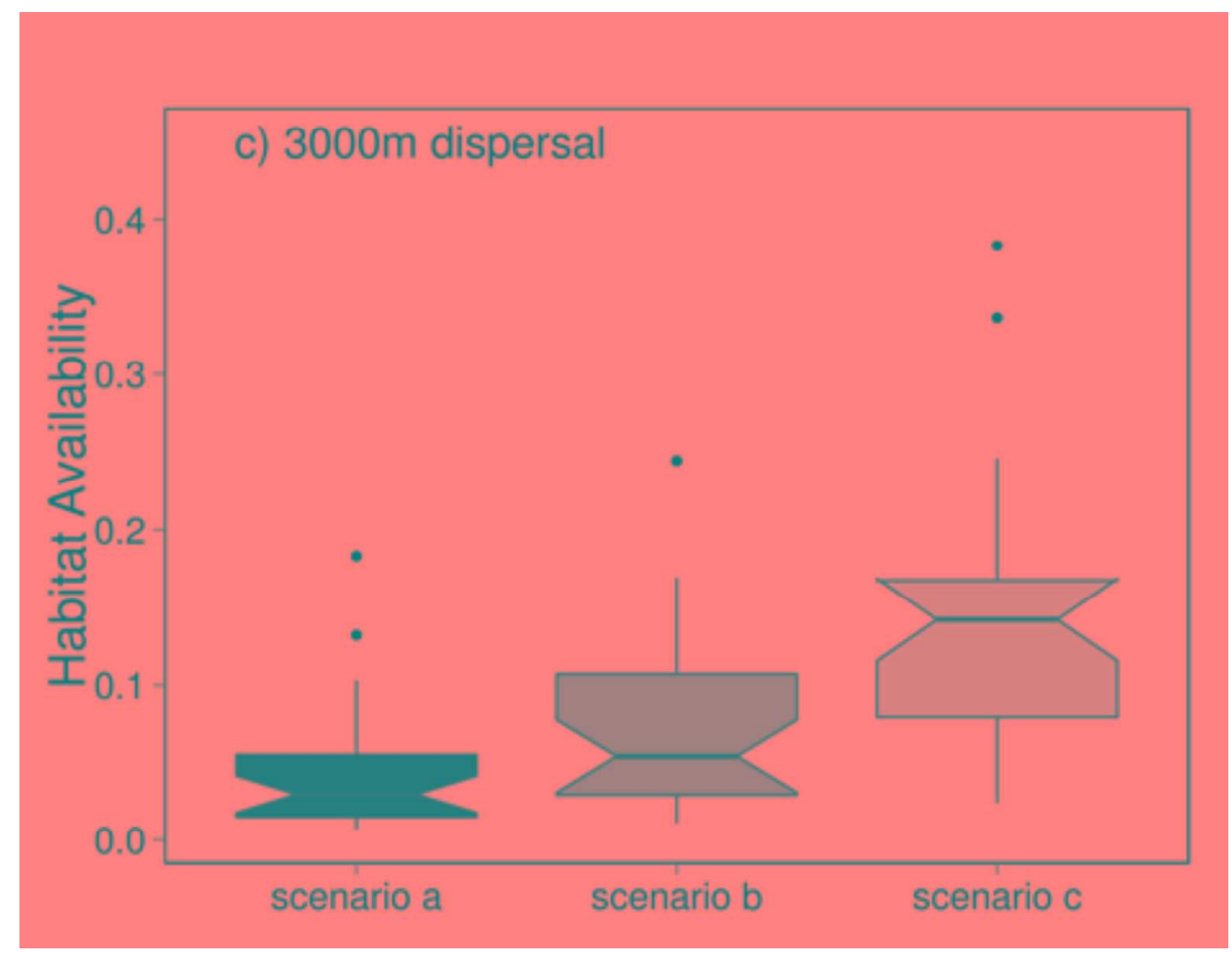

$165 \times 128 \mathrm{~mm}(300 \times 300 \mathrm{DPI})$ 